Tajana Barbić*
Iva Čondic-Jurkic ${ }^{* *}$
UDK 336.763(497.5)

Preliminary paper

Prethodno priopćenje

\title{
EQUITY INVESTMENT STRATEGIES: THE CASE OF CROATIA
}

\begin{abstract}
This paper aims to analyze an investment strategy employed by particular equity investment fund in Croatia, i.e. to detect the fraction of passive funds which claim to be active. In order to test for bilateral long-run co-movements between fifteen selected mutual funds and CROBEX in time period from their start to the end of 2009, we use bivariate Johansen cointegration procedure. Results reveal that most of the Croatian equity funds share long run comovements with benchmark equity market index, representing the "closet indexers". Obtained results are to some extent unexpected given spotted inefficiencies on Croatian equity market that should have been exploited by active stock pickers.
\end{abstract}

Keywords: investment approach, market efficiency, equity investment funds, cointegration

\section{INTRODUCTION}

Depending on investor's goal, risk preference and preferable time span of the investment, equity market investor may choose to put money in various types of mutual funds that can follow active or passive investment strategy. While passively managed fund replicate the return on an index with a strategy of buying and holding all index stocks in the official index proportions, actively managed mutual funds attempt to add value to their shareholders by selecting a portfolio of securities expected to provide a superior risk-return trade-off and monitoring and revising their portfolios continuously in response to the market conditions. Since actively managed funds generate more expenses than the passively managed ones, active management benefits the shareholders only if the excess returns on actively managed portfolios are larger than the incremental cost incurred by the shareholders (Shukla, 2004).

As an alternative to institutional investing, investors may choose to trade on equity market by using individual stock picking skill. The latter approach is considered to be a "high risk-high returns" investment vehicle. Along with higher risk exposure, individual stock picking assumes higher transaction costs in comparison to costs of investment funds due to more frequent individual trading on equity market and costs of market research. On the other hand, investing in mutual funds requires little research, although it is harder for investor to monitor the investment. Having in mind that it is very hard to detect individual stock picking techniques, focus of this paper is put on investing in Croatian equity funds.

\footnotetext{
* MSC, Research Assistant, Institute of Economics, Zagreb, 10000 Zagreb, Trg J. F. Kennedya 7, Phone: ++385(0)12362 290, Fax: ++385(0)2335165, e-mail: tbarbic@eizg.hr

** MSC, Research Assistant, Institute of Economics, Zagreb, 10000 Zagreb, Trg J.F. Kennedya 7, Phone: ++385(0)12362 241, Fax: ++385(0)2335165, e-mail: icondic@eizg.hr
} 
In efficient markets ${ }^{1}$ investors would be better off investing in broad market indices, since active management would fail to add value sufficient to outweigh administration costs and fees given that hard competition between investors results in lack of both abnormal performance on average and persistence in performance. Therefore, significant shift from active to passive management over the 1990s can be partially assigned to market efficiency of developed equity markets which has been showed in earlier studies i.e. Kendall (1953), Fama (1970), Fama and French (1988), Poterba and Summers (1988). In addition to rise of popularity of truly index funds, there is a great number of closet indexers i.e. funds that score low on active management while still claiming to be active (Cremers and Petajisto, 2009).

Active management should be more successful on emerging financial markets due to their high performance and inherent inefficiencies. These markets have exhibited significant growth opportunities, but also high political and economic risks, making emerging markets more volatile than mature markets (De Santis and Imrohoroglu, 1997). It is general belief that inefficiency is inherent to the emerging markets. Emerging markets are generally perceived to be less efficient than developed markets since most of those markets are accompanied by thin trading issues and potential manipulation by larger players. ${ }^{2}$ Therefore, one might expect that there are more opportunities for fund managers to find abnormal returns in emerging than developed markets (Huij and Post, 2008). In particular, financial markets of Central and Eastern European countries experienced the great growth after orientation towards marketbased economy was adopted, foremost due to strong performance over this period with yields in some markets far exceeding those of the industrial financial markets (Cohen, 2001). Investors' interest in these markets became even more pronounced with beginning of a sharp rise in stock prices that coincided with the announcement of EU enlargement in $2001^{3}$. However, recent developments in equity mutual funds industry in CEE countries should be observed in light of financial crisis.

This paper aims to examine investment approaches on Croatian equity market and thereto fill the gap of existing literature on trading strategies of funds investing in Croatian equity market as well as market efficiency. Until the end of 2007, when first index fund- OTP Index has been introduced, all mutual funds on Croatian equity market were actively managed. However, it is possible that some of the equity funds, although declared as active funds, were following the CROBEX anyway. Therefore, it is our intention to distinguish between truly active investment funds and closet indexers. In order to test for such possibility, we use bivariate Johansen cointegration procedure to detect bilateral long-run co-movements between fifteen selected mutual funds and CROBEX in time period from their start to the end of 2009 . In other words, we measure active management by measuring the degree of deviation from passive management.

The rest of the paper is organized as follows. After reviewing some of the literature on mutual funds performance with respect to chosen investment strategy in section 2, in section 3 data and methodology employed are presented. Last two sections, 4 and 5, offer discussion of results of the paper and concluding remarks.

\section{LITERATURE REVIEW}

Number of studies was dealing with performance of mutual funds. Evaluation of managed funds has been concerned on assessing the performance of actively managed investment portfolios. Grossman and Stiglitz (1980) argue that market efficiency in a strict sense cannot 
occur without accounting for informed investors holding costly information. Active investment managers will only incur expenses in obtaining information to become informed when they can be compensated for acquiring price sensitive information. In line with that, these managers should be able to at least earn excess returns equal to the fees levied on the actively managed portfolio in order for capital market efficiency to be in equilibrium. Among studies that support Grossman and Stiglitz (1980) hypothesis one should distinguish those by Daniel et al. (1997) and Wermers (2000) suggesting that the average mutual fund outperforms the benchmark, attributing much of this performance to the characteristics of the stocks held by funds. The latter researcher points out the importance of determining whether the industry as a whole or perhaps industry subgroups has stock-picking talents that justify the trading costs it incurs and the management fees and expenses that it charges.

However, majority of studies dealing with mutual funds performance suggest that actively managed funds fail to earn superior returns to an appropriate benchmark proxy portfolio or index, which is consistent with the efficient markets hypothesis (for example Jensen, 1969; Grinblatt and Titman, 1989, 1993; Elton, Gruber, Das and Hlavka, 1993; Malkiel, 1995; and Gruber, 1996). The literature also confirms that funds do not successfully 'time' the market (Treynor and Mazuy, 1966; Kon, 1983; Chang and Lewellen, 1984; Henriksson, 1984; Lee and Rahman, 1990; Coggin, Fabozzi and Rahman, 1993; Ferson and Schadt, 1996; Daniel, Grinblatt, Titman and Wermers, 1997; and Becker, Ferson, Myers and Schill, 1999; Kothari and Warner, 2001). In most cases, conclusions on performance evaluation are based primarily on the risk-adjusted measures, bringing some concerns regarding misspecification of the model, misspecification of the benchmark or survivor-biased samples of funds. Frequent trade has generally been perceived as an indicator of active management, causing high turnover in the mutual fund portfolios. Shukla (2004) concludes that mutual fund shareholders are not getting any return for the expenses associated with the frequent portfolio revision component of active management. Funds that generate the highest excess returns have small and more concentrated portfolios, and do not have the highest turnover.

It should be pointed out that aforementioned mutual fund literature mainly treats all mutual funds as one homogeneous group. However, Cremers and Petajisto (2009) develop methodology that distinguishes between different types of active funds as well as focuses on the ones that are truly active. They point out that active management of all equity mutual funds should be measured in two dimensions: tracking error and Active Share. Tracking error measures the volatility of portfolio return around a benchmark index, whereas Active Share measures the deviation of portfolio holdings from the holdings of the benchmark index. Such approach facilitates identification of following types of active management: diversifed stock picks, concentrated stock picks, factor bets, closet indexing, and pure indexing. Results show that funds with the highest Active Share, smallest assets, and best one-year performance seem very attractive even after fees and transaction costs, outperforming their benchmarks by about $6 \%$ per year. A possible explanation for the performance results is that there are enough small inefficiencies in the pricing of individual stocks to allow the most active stock pickers to generate a positive alpha, and this is the dimension captured by Active Share. Furthermore, about half of all active positions at the fund level cancel out within the mutual fund sector, thus making the aggregate mutual fund positions even less active. Economically, these results suggest that the most active diversified stock pickers and concentrated stock pickers have enough skill to generate alphas that remain positive even after fees and transaction costs. In contrast, funds focusing on factor bets seem to have zero to negative skill, which leads to particularly bad performance after fees. Hence, it appears that there are some mispricings in individual stocks that active managers can exploit, but broader factor portfolios are either too 
efficiently priced to allow any alphas or too difficult for the managers to predict. Closet indexers, unsurprisingly, exhibit zero skill but underperform because of their expenses.

Aforementioned findings are mostly based on performance of fund industry in developed markets. On the other hand, there is serious lack of related literature on emerging markets, especially ones in Central and Eastern Europe. Gottesman and Morey (2007) investigate predictability in the performance of emerging market funds by employing a regression framework and testing the ability of several fund characteristics, including the expense ratio, turnover, fund size, manager tenure and past performance, to predict emerging market fund performance. Surprisingly, they find that the expense ratio is the only fund characteristic that appears to consistently predict future fund performance. Specifically, emerging market funds with lower expenses show better performance. Moreover, authors find some limited evidence that passive management may outperform active management in emerging market funds.

Huij and Post (2008) suggest that emerging market funds generally display better performance than US funds. They show that there is strong persistence in the performance of emerging market funds with the winner funds outperforming the market by more than 4 percent per annum. Their results are consistent with the view that emerging markets are less efficient than developed markets, and that there are more opportunities for fund managers to find abnormal returns in emerging markets. Moreover, one of the differences between emerging market funds and other funds is that use of short selling and derivatives was relatively limited in the previous two decades because such instruments were not as readily available as they are in developed capital markets (Eling and Faust, 2010).

Although individual stock picking is not going to be assessed in this paper, it should be noted that Bhattacharya and Galpin (2009) developed a metric to measure the maximum fraction of volume explained by stock picking in a market. In other words, aforementioned researchers assume that every person in the world chooses between a risk-free portfolio and a valueweighted portfolio, hence trading volume in particular stock should be explained completely by the weight of the same stock in the value-weighted portfolio. Results showed that stock picking was declining although there was more of it in emerging markets than in developed countries. Moreover, stock picking is more prominent in markets where there is less public disclosure of stock-specific information, because stock pickers can only make money when they have better information than everyone else (Bhattacharya and Galpin, 2009). Improvement of disclosure over time should make stock picking less profitable and, therefore, less popular investment approach. Morck et al. (2000) showed that public information disclosure is better in developed markets than in emerging markets, and in both markets, public information disclosure is improving over time. Therefore, individual stock picking should be more popular in emerging markets than in developed markets.

Similarly, Khorana et al. (2005) argue that countries with more stringent regulatory approval and disclosure requirements for funds tend to have a larger fund industry. In other words, stronger regulation that specifically protects fund investors may be beneficial to the fund industry. Furthermore, they find that wealthier countries have larger mutual fund industries. These effects are particularly pronounced for the equity funds, which may require a higher level of investor sophistication. Moreover, mutual funds are more developed in countries in which a larger fraction of pension plans are defined contribution plans. Finally, countries whose trading costs are lower have more developed fund industry, which indicates that the ability to offer liquidity at a low cost is important for the industry's growth. Overall, these results suggest that mutual funds thrive in more developed economies. 


\section{DATA AND METHODOLOGY}

\subsection{DATA}

The data set consists of time series representing net asset value of particular investment fund and closing prices of the general index of Zagreb Stock Exchange (CROBEX) on daily basis. Time series are denominated in local currency and we used logarithmic transformation of original data. Regarding fund selection, among 48 equity investment funds in Croatia we took into consideration 15 of them that put more than $50 \%$ of the fund's assets in stocks and hold more than one third of its portfolio in stocks listed on Zagreb Stock Exchange. The observed funds are: A1, Capital Two, Erste Adriatic Equity, Erste Total East, FIMA Equity, HIGrowth, HPB Equity Fund, KD Victoria, OTP Meridien 20, PBZ Equity, Poba Ico Equity, Prospectus JIE, Raiffeisen C. Europe, RBA HR Stocks and ST Global Equity. It is important to outline that none of these investment funds are index funds with a declared aim to replicate the performance of the market portfolio or benchmark exactly. ${ }^{4}$ Time span for various series in data set is not unique given that investment fund industry in Croatia is rather young. Thus, particular data series representing NAV of the investment funds begins with the fund's first working day, while all data series terminate on December $31^{\text {st }}, 2009$. The source for investment funds data was web portal www.hrportfolio.com, providing us with internal data, while the data for official index of Zagreb Stock Exchange CROBEX were taken from Zagreb Stock Exchange database.

\subsection{METHODOLOGY}

Financial data series usually follow a random walk pattern and in most cases exhibit nonstationarity in levels. Augmented Dickey-Fuller procedure (Dickey and Fuller, 1979) will be used to test for existence of unit roots in both the price levels and first difference of stock market index CROBEX and net asset value of particular investment fund. The test for a unit root has the null hypothesis that $\gamma=0$. Optimal number of time lags is to be determined by Modified Akaike Information Critera (MAIC).

In order to test weather investor could earn above-average returns on Croatian equity market by using merely technical analysis. After performing ADF test, if the time series is difference stationary, further analysis is needed since presence of a unit root is not a sufficient condition for a random walk (Campbell, Lo, MacKinlay, 1997). Therefore, tests of autocorrelation are employed in order to examine randomness in data.

In order to test for a potential long run equilibrium relationship between particular mutual fund and CROBEX, i.e. to test whether particular investment fund could have served as a substitute for direct portfolio investment from the standpoint of a long-term investor, cointegration analysis will be employed. Cointegration analyses consider a setting where between two time series, typically non-stationary in levels, exists a linear combination of the same "d" integrability order that exhibit $\mathrm{I}(<\mathrm{d})$ property. If two series are cointegrated, that implies they move together over time maintaining long term equilibrium, although short term disturbances are allowed (Engle and Granger, 1987). To test for the presence of such relationship, we use Johansen cointegration procedure which assumes that for $n$ variables there might exist $n-1$ different linear combinations of variables that are stationary. Johansen (1991) offers a procedure which detects cointegration by testing cointegration rank and by identifying and estimating cointegrating coefficients matrix. 
If $n$ number of variables exhibit nonstationarity in levels and are cointegrated, vector autoregression model (VAR) should be transformed into vector error correction model ${ }^{5}$ (VECM) as follows:

$\Delta Y_{t}=\Pi Y_{t-k}+\Gamma_{1} \Delta Y_{t-1}+\Gamma_{2} \Delta Y_{t-2}+\ldots .+\Gamma_{k-1} \Delta Y_{t-(k-1)}+u_{t}$

where $\Pi=\left(\sum_{i=1}^{k} \beta_{i}\right)-I_{n}$ stands for long run parameters, while $\Gamma_{i}=\left(\sum_{j=1}^{i} \beta_{j}\right)-I_{n}$ stands for short run parameters.

Matrix $\Pi$ is defined as a product of two matrices, $A$ and $B^{\prime}$, of dimension ( $\left.\mathrm{g} \times \mathrm{r}\right)$ and $(\mathrm{r} \times \mathrm{g})$, respectively, i.e. $\Pi=A B^{\prime}$. The matrix $B$ gives the cointegrating vectors (betas), while $A$ gives the adjustment parameters (alphas) which determine the amount of each cointegrating vector entering each equation of the VECM.

\section{RESULTS}

The results of the empirical analysis are reported in tables 1-4. Table 1 shows results of unit root tests in levels and first differences for logarithmic transformation of CROBEX and net asset values of selected equity investment funds. Results reveal that the null hypothesis about unit root existence in levels can not be rejected in case of any variable. Null hypothesis about unit root existence in first differences is rejected for all variables. Therefore, empirical analysis will be proceeded to the second step by assuming that investment funds' NAVs and CROBEX are integrated of order 1, i.e. I(1). 
Table 1

\section{ADF unit root tests - in levels and in differences}

\begin{tabular}{|c|c|c|c|c|c|}
\hline \multirow[b]{2}{*}{ Variable } & \multirow{2}{*}{$\begin{array}{l}\text { Time period } \\
\text { (dd.mm.yy) }\end{array}$} & \multicolumn{2}{|c|}{ ADF in levels } & \multicolumn{2}{|c|}{ ADF in differences } \\
\hline & & $\begin{array}{l}\text { t-value (trend } \\
\text { included) }\end{array}$ & p-value & $\begin{array}{l}\text { t-value (trend } \\
\text { included) }\end{array}$ & p-value \\
\hline CROBEX & $07.10 .99-31.12 .09$ & $-1.95636(15)$ & 0.3065 & $-9.72357 *(17)$ & 0.0000 \\
\hline KD Victoria & $07.10 .99-31.12 .09$ & $1.094588(13)$ & 0.9999 & $-9.06352 *(18)$ & 0.0000 \\
\hline ST Global Equity & $02.01 .02-31.12 .09$ & $-0.81746(15)$ & 0.9627 & $-8.24926 *(22)$ & 0.0000 \\
\hline HI-Growth & $25.02 .02-31.12 .09$ & $-1.37182(15)$ & 0.8689 & $-7.51320 *(19)$ & 0.0000 \\
\hline FIMA Equity & $01.06 .04-31.12 .09$ & $-0.89488(20)$ & 0.9549 & $-5.33292 *(19)$ & 0.0000 \\
\hline RBA Central Europe & $19.04 .05-31.12 .09$ & $-1.60132(18)$ & 0.7923 & $-5.05831 *(18)$ & 0.0002 \\
\hline PBZ Equity & $05.09 .05-31.12 .09$ & $-1.54895(15)$ & 0.8121 & $-5.35055 *(15)$ & 0.0000 \\
\hline HPB Equity Fund & $04.10 .05-31.12 .09$ & $-0.69686(11)$ & 0.8454 & $-6.10645 *(13)$ & 0.0000 \\
\hline Erste Adriatic Equity & $10.10 .05-31.12 .09$ & $-0.93614(17)$ & 0.7769 & $-5.05702 *(19)$ & 0.0002 \\
\hline Prospectus JIE & $30.01 .07-31.12 .09$ & $-1.942512(3)$ & 0.6310 & $-4.44122 *(18)$ & 0.0020 \\
\hline Capital Two & $07.04 .07-31.12 .09$ & $-0.524415(3)$ & 0.8837 & $-4.76669 *(16)$ & 0.0006 \\
\hline Poba Ico Equity & $27.07 .07-31.12 .09$ & $-1.12693(10)$ & 0.9224 & $-4.15146 *(18)$ & 0.0056 \\
\hline Erste Total East & $02.10 .07-31.12 .09$ & $-0.415471(3)$ & 0.9868 & $-3.5370 * *(16)$ & 0.0365 \\
\hline OTP Meridien 20 & $08.04 .08-31.12 .09$ & $-0.900797(2)$ & 0.9537 & $-3.6201 * *(17)$ & 0.0293 \\
\hline A1 & $19.05 .08-31.12 .09$ & $-1.594124(2)$ & 0.4847 & $-4.78037 *(11)$ & 0.0006 \\
\hline RBA HR Stocks & $08.04 .08-31.12 .09$ & $-2.540536(3)$ & 0.3084 & $-2.8830 * *(15)$ & 0.0485 \\
\hline
\end{tabular}

Note: optimal number of time lags determined with Modified Akaike Information Criterion (AIC) and is presented in parenthesis; * null hypothesis about existence of unit root rejected at 1 percent level, ** null hypothesis about existence of unit root rejected at 5 percent level, *** null hypothesis about existence of unit root rejected at 10 percent level.

Results of unit roots tests show that CROBEX index exhibits nonstationarity in levels and stationarity in first differences. Regarding the fact that presence of a unit root is a necessary but not a sufficient condition for a random walk process, further analysis is needed in order to examine weather CROBEX developments are predictable. Therefore, autocorrelation analysis is performed for 12 lags of daily, weekly and monthly data. ${ }^{6}$

Results of autocorrelation analysis performed on daily, weekly and monthly returns are presented in Table 2. Within entire observed period of daily data significant (positive sign) ${ }^{7}$ autocorrelation coefficient is found at $3^{\text {rd }}, 5^{\text {th }}, 8^{\text {th }}$ and $10^{\text {th }}$ lag, while significant (negative sign) autocorrelation coefficient is detected at 7 th lag. Weekly data exhibit significant (positive sign) autocorrelation coefficient at $1^{\text {st }}, 2^{\text {nd }}$ and $6^{\text {th }}$ lag. Finally, significant (positive sign) autocorrelation coefficient is found exclusively at $1^{\text {st }}$ lag of monthly data. The results of autocorrelation tests are consistent with the findings of significant predictability in emerging market returns (Harvey, 1994; Claessens, Dasgupta and Glen, 1995). One of the possible reasons for serial correlation in daily returns of CROBEX is low market liquidity that was pronounced in period 1997-2000. ${ }^{8}$ In addition to infrequent trading other reasons such as improved regulatory and institutional structure, valuation of listed shares and higher degree of financial integration may be offered as a possible explanation of such tendency. 
Table 2

Autocorrelation of CROBEX returns, 1997-2009

\begin{tabular}{ccccccc}
\hline \multirow{2}{*}{ Lag } & \multicolumn{2}{c}{ Daily returns } & \multicolumn{2}{c}{ Weekly returns } & \multicolumn{2}{c}{ Monthly returns } \\
\cline { 2 - 7 } & $\boldsymbol{\tau}_{\mathbf{k}}$ & $\mathbf{Q}$ & $\boldsymbol{\tau}_{\mathbf{k}}$ & $\mathbf{Q}$ & $\boldsymbol{\tau}_{\mathbf{k}}$ & $\mathbf{Q}$ \\
\hline 1 & -0.021 & $\begin{array}{c}1.467 \\
{[0.226]}\end{array}$ & $0.233^{*}$ & $\begin{array}{c}33.04 \\
{[0.000]}\end{array}$ & $0.222^{*}$ & $\begin{array}{c}7.67 \\
{[0.006]}\end{array}$ \\
\hline 2 & 0.016 & $\begin{array}{c}2.332 \\
{[0.321]}\end{array}$ & $0.120^{*}$ & $\begin{array}{c}41.75 \\
{[0.000]}\end{array}$ & 0.048 & $\begin{array}{c}8.04 \\
{[0.018]}\end{array}$ \\
\hline 3 & $0.068^{*}$ & $\begin{array}{c}17.62 \\
{[0.001]}\end{array}$ & 0.009 & $\begin{array}{c}41.79 \\
{[0.000]}\end{array}$ & 0.037 & $\begin{array}{c}8.36 \\
{[0.039]}\end{array}$ \\
\hline 4 & -0.031 & $\begin{array}{c}20.72 \\
{[0.000]}\end{array}$ & 0.026 & $\begin{array}{c}42.19 \\
{[0.000]}\end{array}$ & -0.017 & $\begin{array}{c}8.41 \\
{[0.078]}\end{array}$ \\
\hline 5 & $0.033^{*}$ & $\begin{array}{c}24.33 \\
{[0.000]}\end{array}$ & 0.003 & $\begin{array}{c}42.19 \\
{[0.000]}\end{array}$ & 0.061 & $\begin{array}{c}8.99 \\
{[0.109]}\end{array}$ \\
\hline 6 & -0.030 & $\begin{array}{c}27.24 \\
{[0.000]}\end{array}$ & $0.092 *$ & $\begin{array}{c}47.45 \\
{[0.000]}\end{array}$ & -0.129 & $\begin{array}{c}11.68 \\
{[0.0 .69]}\end{array}$ \\
\hline 7 & $-0.042 *$ & $\begin{array}{c}33.01 \\
{[0.000]}\end{array}$ & 0.017 & $\begin{array}{c}47.63 \\
{[0.000]}\end{array}$ & 0.037 & $\begin{array}{c}11.91 \\
{[0.104]}\end{array}$ \\
\hline 8 & $0.064 *$ & $\begin{array}{c}46.39 \\
{[0.000]}\end{array}$ & 4.047 & $\begin{array}{c}48.99 \\
{[0.000]}\end{array}$ & 0.084 & $\begin{array}{c}13.06 \\
{[0.110]}\end{array}$ \\
\hline 9 & -0.014 & $\begin{array}{c}47.03 \\
{[0.000]}\end{array}$ & 0.003 & $\begin{array}{c}49.01 \\
{[0.000]}\end{array}$ & -0.032 & $\begin{array}{c}13.23 \\
{[0.152]}\end{array}$ \\
\hline 10 & $0.043 *$ & $\begin{array}{c}53.06 \\
{[0.000]}\end{array}$ & -0.019 & $\begin{array}{c}49.22 \\
{[0.000]}\end{array}$ & 0.064 & $\begin{array}{c}13.92 \\
{[0.177]}\end{array}$ \\
\hline 11 & 0.036 & $\begin{array}{c}57.44 \\
{[0.000]}\end{array}$ & 0.031 & $\begin{array}{c}49.81 \\
{[0.000]}\end{array}$ & -0.021 & $\begin{array}{c}13.99 \\
{[0.233]}\end{array}$ \\
\hline 12 & 0.008 & $\begin{array}{c}57.66 \\
{[0.000]}\end{array}$ & 0.027 & $\begin{array}{c}50.26 \\
{[0.000]}\end{array}$ & 0.037 & $\begin{array}{c}14.22 \\
{[0.287]}\end{array}$ \\
\hline
\end{tabular}

*significant auto-correlation at two standard error limits

Although results of performed autocorrelation tests suggest existence of inefficiencies on Croatian equity market, in line with aforementioned arguments, hypothesis about possibility of earning above average returns by simply using technical analysis can not be neither accepted nor rejected. Therefore, in further research, more developed predictive models should be built and potential profitability of the formed trading rules should be examined. Being impossible to conclude that all investors had beaten the market all the time, we might presume there some individual investors could have take advantage of some observed inefficiencies.

In the next step of our analysis we intend to distinguish truly active investment funds from closet indexers. In line with our aim, we use bivariate Johansen cointegration procedure to detect bilateral long-run co-movements between fifteen selected mutual funds and CROBEX in time period from their start to the end of 2009. In other words, we measure active management by measuring the degree of deviation from passive management. Results of bivariate Johansen cointegration procedure are summarised in Table 3. 
Table 3

Results of Johansen cointegration procedure for pairs of variables

\begin{tabular}{|c|c|c|c|c|c|c|c|}
\hline & Lags & $\begin{array}{c}\text { Hypothesized } \\
\text { no. of CE(s) }\end{array}$ & $\begin{array}{l}\text { Eigen } \\
\text { value }\end{array}$ & $\lambda$ trace & $\begin{array}{c}5 \% \\
\text { critical } \\
\text { value }\end{array}$ & $\lambda \max$ & $\begin{array}{c}5 \% \\
\text { critical } \\
\text { value }\end{array}$ \\
\hline \multirow{2}{*}{$\begin{array}{l}\text { CROBEX- } \\
\text { KDVictoria } \\
\end{array}$} & \multirow{2}{*}{1} & None & 0.012484 & 35.49291 & 25.87211 & 31.99676 & 19.38704 \\
\hline & & At most 1 & 0.001372 & 3.496154 & 12.51798 & 3.496154 & 12.51798 \\
\hline \multirow{2}{*}{ CROBEX-A1 } & \multirow{2}{*}{1} & None* & 0.152048 & 70.79998 & 25.87211 & 66.79735 & 19.38704 \\
\hline & & At most 1 & 0.009834 & 4.002628 & 12.51798 & 4.002628 & 12.51798 \\
\hline \multirow{2}{*}{$\begin{array}{l}\text { CROBEX- } \\
\text { HPB Equity }\end{array}$} & \multirow{2}{*}{7} & None* & 0.046946 & 54.98755 & 25.87211 & 50.87289 & 19.38704 \\
\hline & & At most 1 & 0.003882 & 4.114664 & 12.51798 & 4.114664 & 12.51798 \\
\hline \multirow{2}{*}{$\begin{array}{l}\text { CROBEX- } \\
\text { CapitalTwo } \\
\end{array}$} & \multirow{2}{*}{2} & None* & 0.059524 & 46.27766 & 25.87211 & 41.36274 & 19.38704 \\
\hline & & At most 1 & 0.007266 & 4.914915 & 12.51798 & 4.914915 & 12.51798 \\
\hline \multirow{2}{*}{$\begin{array}{l}\text { CROBEX- } \\
\text { ErsteAdriatic }\end{array}$} & \multirow{2}{*}{7} & None* & 0.072376 & 84.66163 & 25.87211 & 79.18601 & 19.38704 \\
\hline & & At most 1 & 0.005182 & 5.475614 & 12.51798 & 5.475614 & 12.51798 \\
\hline \multirow{2}{*}{$\begin{array}{l}\text { CROBEX- } \\
\text { ErsteTotalEast** }\end{array}$} & \multirow{2}{*}{3} & None & 0.039874 & 24.46504 & 25.87211 & 22.78697 & 19.38704 \\
\hline & & At most 1 & 0.002992 & 1.678074 & 12.51798 & 1.678074 & 12.51798 \\
\hline \multirow{2}{*}{$\begin{array}{l}\text { CROBEX- } \\
\text { FimaEquity }\end{array}$} & \multirow{2}{*}{3} & None* & 0.046481 & 74.39153 & 25.87211 & 66.63400 & 19.38704 \\
\hline & & At most 1 & 0.005526 & 7.757532 & 12.51798 & 7.757532 & 12.51798 \\
\hline \multirow{2}{*}{$\begin{array}{l}\text { CROBEX- } \\
\text { HIGrowth }\end{array}$} & \multirow{2}{*}{7} & None* & 0.013921 & 28.98312 & 25.87211 & 27.53356 & 19.38704 \\
\hline & & At most 1 & 0.000738 & 1.449567 & 12.51798 & 1.449567 & 12.51798 \\
\hline \multirow{2}{*}{$\begin{array}{l}\text { CROBEX- } \\
\text { OTPMeridien20 }\end{array}$} & \multirow{2}{*}{2} & None* & 0.144141 & 69.35542 & 25.87211 & 65.06152 & 19.38704 \\
\hline & & At most 1 & 0.010220 & 4.293893 & 12.51798 & 4.293893 & 12.51798 \\
\hline \multirow{2}{*}{$\begin{array}{l}\text { CROBEX- } \\
\text { PBZEquity }\end{array}$} & \multirow{2}{*}{7} & None* & 0.053360 & 64.43827 & 25.87211 & 59.16843 & 19.38704 \\
\hline & & At most 1 & 0.004872 & 5.269840 & 12.51798 & 5.269840 & 12.51798 \\
\hline \multirow{2}{*}{$\begin{array}{l}\text { CROBEX- } \\
\text { PobaIcoEquity } \\
\end{array}$} & \multirow{2}{*}{3} & None* & 0.146416 & 98.02511 & 25.87211 & 95.93670 & 19.38704 \\
\hline & & At most 1 & 0.003440 & 2.088145 & 12.51798 & 2.088415 & 12.51798 \\
\hline \multirow{2}{*}{$\begin{array}{l}\text { CROBEX- } \\
\text { ProspectusJIE }\end{array}$} & \multirow{2}{*}{3} & None* & 0.119448 & 97.32846 & 25.87211 & 92.73353 & 19.38704 \\
\hline & & At most 1 & 0.006283 & 4.594931 & 12.51798 & 4.594931 & 12.51798 \\
\hline \multirow{2}{*}{$\begin{array}{l}\text { CROBEX- } \\
\text { RBAC.Eur } \\
\end{array}$} & \multirow{2}{*}{7} & None* & 0.045933 & 60.77604 & 25.87211 & 55.27686 & 19.38704 \\
\hline & & At most 1 & 0.004673 & 5.499185 & 12.51798 & 5.499185 & 12.51798 \\
\hline \multirow{2}{*}{$\begin{array}{l}\text { CROBEX- } \\
\text { RBAHrStocks } \\
\end{array}$} & \multirow{2}{*}{3} & None* & 0.293438 & 119.1410 & 25.87211 & 109.0659 & 19.38704 \\
\hline & & At most 1 & 0.031577 & 10.07507 & 12.51798 & 10.07507 & 12.51798 \\
\hline \multirow{2}{*}{$\begin{array}{l}\text { CROBEX- } \\
\text { STGlobal }\end{array}$} & \multirow{2}{*}{1} & None & 0.008304 & 18.53333 & 25.87211 & 16.73501 & 19.38704 \\
\hline & & At most 1 & 0.000896 & 1.798325 & 12.51798 & 1.798325 & 12.51798 \\
\hline
\end{tabular}

* denotes rejection of hypothesis at the 0.05 level; **according to $\lambda_{\max }$ there is one cointegrating vector

Note: optimal number of time lags selected using Hannah-Quinn criteria obtained after VAR estimation of all endogenous variables and used in VECM

We found one cointegrating vector in almost all tested bilateral cases between CROBEX and particular investment fund. The exceptions were cases of KD Victoria, Erste Total East and ST Global Equity fund on the one side and CROBEX on the other. This means that those three investment funds are truly active. All other tested investment funds exhibit long run relationship with CROBEX, representing the fraction of passive funds which claim to be active. In other words, results of our analysis reveal those investment funds to be closet indexers.

In Table 4 we present the results of the tested hypothesis about both the parameters in the cointegrating vector and their loading in the VECM. 
Table 4

Parameters in the cointegrating vector and adjustment parameters from VECM

\begin{tabular}{|c|c|c|c|c|c|}
\hline & \multicolumn{3}{|c|}{$\begin{array}{c}\text { Cointegrating Vector Parameters } \\
\text { (betas) }\end{array}$} & \multicolumn{2}{|c|}{$\begin{array}{l}\text { Adjustment parameters in } \\
\text { VECM (alphas) }\end{array}$} \\
\hline & CROBEX & $\begin{array}{l}\text { Investment } \\
\text { Fund }\end{array}$ & Constant & CROBEX & $\begin{array}{l}\text { Investment } \\
\text { Fund }\end{array}$ \\
\hline CROBEX-A1 & 1.00000 & $\begin{array}{l}-2.171842^{*} \\
(1.849559)\end{array}$ & 1.849559 & $\begin{array}{l}-0.041887 \\
(-5.24371)\end{array}$ & $\begin{array}{l}-0.005075^{*} \\
(-1.14464)\end{array}$ \\
\hline $\begin{array}{l}\text { CROBEX- } \\
\text { HPB Equity }\end{array}$ & 1.00000 & $\begin{array}{l}-1.180780 \\
(-48.7077)\end{array}$ & -1.920673 & $\begin{array}{l}-0.056559 \\
(-6.03970)\end{array}$ & $\begin{array}{l}-0.016176 \\
(-3.65640)\end{array}$ \\
\hline $\begin{array}{l}\text { CROBEX- } \\
\text { CapitalTwo } \\
\end{array}$ & 1.00000 & $\begin{array}{l}-1.933259 \\
(-12.4700) \\
\end{array}$ & 0.734147 & $\begin{array}{c}-0.044474 \\
(-6.35700) \\
\end{array}$ & $\begin{array}{l}-0.004781^{*} \\
(-1.49206)\end{array}$ \\
\hline $\begin{array}{l}\text { CROBEX- } \\
\text { ErsteAdriatic }\end{array}$ & 1.00000 & $\begin{array}{l}-1.395559 \\
(-83.2322)\end{array}$ & 1.777094 & $\begin{array}{l}-0.109431 \\
(8.94554)\end{array}$ & $\begin{array}{l}-0.005390^{*} \\
(-0.83881)\end{array}$ \\
\hline $\begin{array}{l}\text { CROBEX- } \\
\text { FimaEquity }\end{array}$ & 1.00000 & $\begin{array}{l}-1.034005 \\
(31.9847)\end{array}$ & -2.030021 & $\begin{array}{l}-0.026481 \\
(-6.42615)\end{array}$ & $\begin{array}{l}-0.009656 \\
(-5.01131)\end{array}$ \\
\hline $\begin{array}{l}\text { CROBEX- } \\
\text { HIGrowth } \\
\end{array}$ & 1.00000 & $\begin{array}{l}-1.645669 \\
(-16.2503) \\
\end{array}$ & -0.226529 & $\begin{array}{l}-0.014497 \\
(-5.17497) \\
\end{array}$ & $\begin{array}{c}0.001199^{*} \\
(0.84996)\end{array}$ \\
\hline $\begin{array}{l}\text { CROBEX- } \\
\text { OTPMeridien20 }\end{array}$ & 1.00000 & $\begin{array}{l}-1.374592 \\
(-33.9605)\end{array}$ & -1.819010 & $\begin{array}{l}-0.146095 \\
(-8.31593)\end{array}$ & $\begin{array}{l}-0.008594^{*} \\
(-0.82666)\end{array}$ \\
\hline $\begin{array}{l}\text { CROBEX- } \\
\text { PBZEquity }\end{array}$ & 1.00000 & $\begin{array}{l}-1.121232 \\
(-66.6624)\end{array}$ & -1.838147 & $\begin{array}{l}-0.085132 \\
(-7.66018)\end{array}$ & $\begin{array}{l}-0.006786^{*} \\
(-0.98566)\end{array}$ \\
\hline $\begin{array}{l}\text { CROBEX- } \\
\text { PobaIcoEquity }\end{array}$ & 1.00000 & $\begin{array}{l}-1.605326 \\
(-37.4021) \\
\end{array}$ & 6.366389 & $\begin{array}{l}-0.134621 \\
(-10.0544) \\
\end{array}$ & $\begin{array}{r}-0.011469^{*} \\
(-1.43311) \\
\end{array}$ \\
\hline $\begin{array}{l}\text { CROBEX- } \\
\text { ProspectusJIE }\end{array}$ & 1.00000 & $\begin{array}{l}-0.974238 \\
(-37.2833)\end{array}$ & -3.855888 & $\begin{array}{l}-0.111786 \\
(-9.74536)\end{array}$ & $\begin{array}{c}-0.009934^{*} \\
(-1.25899)\end{array}$ \\
\hline $\begin{array}{l}\text { CROBEX- } \\
\text { RBAC.Eur }\end{array}$ & 1.00000 & $\begin{array}{l}-0.956162 \\
(-59.4298) \\
\end{array}$ & -0.295846 & $\begin{array}{l}-0.067253 \\
(-7.24717) \\
\end{array}$ & $\begin{array}{l}-0.012258 \\
(2.02129) \\
\end{array}$ \\
\hline $\begin{array}{l}\text { CROBEX- } \\
\text { RBAHrStocks }\end{array}$ & 1.00000 & $\begin{array}{l}-1.102222 \\
(-69.2252)\end{array}$ & -3.580329 & $\begin{array}{c}0.012136^{*} \\
(0.24676)\end{array}$ & $\begin{array}{l}0.326321 \\
(11.2720)\end{array}$ \\
\hline
\end{tabular}

Note: t-statistics in parenthesis. ${ }^{*}$ denotes statistical insignificance.

All of cointegrating vector parameters presented in Table 4 have expected sign and are statistically significant (except in case of A1 fund). The final result of cointegration analysis are following long run equilibrium relationships:

Crobex $_{t}=1.180780 \mathrm{HpbEq}_{t}+1.920673$

Crobex $_{t}=1.933259$ CapTwo $_{t}-0.734147$

Crobex $_{t}=1.395559$ ErsteAdr $_{t}-1.777094$

Crobex $_{t}=1.034005$ FimaEqt $_{t}+2.030021$

Crobex $_{t}=1.645669$ HIGrowth $_{t}+0.226529$

Crobex $_{t}=1.374592$ OtpMer20 $_{t}+1.819010$

Crobex $_{t}=1.121232$ PbzEquity $_{t}+1.838147$

Crobex $_{t}=1.605326$ PobaIcoEq $_{t}-6.366389$

Crobex $_{t}=0.974238$ Prospectus $_{t}+3.855888$

Crobex $_{t}=0.956162$ RbaCEur $_{t}+0.295846$

Crobex $_{t}=1.102222 \mathrm{RbaHrSt}_{t}+3.580329$ 
The interpretation should be as follows: for example, in case of cointegration between CROBEX and HPB Equity Fund, increase of CROBEX by $1 \%$ leads to the rise of the Fund by $1.18078 \%$. The rest of the cointegration equation should be interpreted in the same manner.

We proceed to the analysis of adjustment coefficients that are results of VECM and are also presented in the Table 4. The adjustment coefficients measure the speed of adjustment (in one period) at which short run deviations are brought back to long run equilibrium. For example, in case of CROBEX and HPB Equity Fund, if CROBEX diverges from the long run equilibrium, it will fall/rise by $5.66 \%$ daily in order to return to the equilibrium. That implies it takes 40 days till approximately $90 \%$ adjustment is achieved. In the same vein, if HPB Equity Fund is under/below the long run equilibrium, its net asset value will fall/rise by $1.62 \%$ daily to return to the equilibrium. Adjustment coefficients for other pairs of variables will not be interpreted in the text for the sake of space savage, but follow the manner of interpretation.

\section{CONCLUSION}

In efficient markets investors would be better off investing in broad market indices, since active management would fail to add value sufficient to outweigh administration costs and fees given that hard competition between investors results in lack of both abnormal performance on average and persistence in performance. Therefore, significant shift from active to passive management over the 1990s can be partially assigned to market efficiency of developed equity markets. In addition to rising popularity of pure index funds, there is a great number of closet indexers i.e. funds that score low on active management while still claiming to be active.

On the other hand, active management should be more successful on emerging financial markets due to their high performance opportunities and inherent inefficiencies accompanied by high volatility, thin trading issues and potential manipulation by larger players. Hence it is generally perceived that emerging markets offer more opportunities for fund managers to find abnormal returns on average. Croatian equity market, like other equity emerging markets, experienced the great growth in last decade, foremost due to strong performance over this period with yields in some markets far exceeding those of the industrial financial markets. Moreover, results of performed autocorrelation analysis indicate that CROBEX does not follow random walk model. Despite that, transaction costs and infrequent and nonsynchronous trading that are usually inherent to emerging equity markets should be accounted when deciding on market efficiency.

Having analyzed the possibility of generating above average returns due to market inefficiencies, the main aim of this paper is to detect investment strategy employed by particular equity investment funds in Croatia in order to distinguish between truly active equity investment funds and closet indexers in Croatia. Results of Johansen cointegration analysis reveal that A1, Capital Two, Erste Adriatic Equity, FIMA Equity, HI-Growth, HPB Equity Fund, OTP Meridien 20, PBZ Equity, Poba Ico Equity, Prospectus JIE, Raiffeisen Central Europe, RBA HR Stocks are closet indexers. More precisely, aforementioned funds share long run comovements with benchmark equity market index representing the fraction of passive funds which claim to be active. On the other hand, KD Victoria, Erste Total East, ST Global Equity follow truly active investment strategy. Obtained results are to some extent unexpected given spotted inefficiencies on Croatian equity market that should have been 
exploited by active stock pickers. However, we might presume there some institutional as well as individual stock pickers could have taken advantage of some observed inefficiencies. However, in order have clear understanding, more developed predictive models should be built and potential profitability of the formed trading rules should be examined. Nevertheless, recent developments in equity investment funds industry on Croatian equity market should be observed in light of financial crisis. Investment funds sharing the long run comovements with CROBEX could be explained with a fact that entire market has been facing the same downturn trend since the end of 2007.

\section{REFERENCES:}

Abrosimova, N., Dissanaike, G., Linowski, D. (2002), "Testing Weak-Form Efficiency of the Russian Stock Market", EFA 2002 Berlin Meeting.

Becker, C., Ferson, W., Myers, D., Schill, M. (1999), "Conditional market timing with benchmark investors", Journal of Financial Economics, 52:119-148.

Bhattacharya, U., Galpin, N. E. (2009), "The Global Rise of the Value-Weighted Portfolio", Journal of Financial and Quantitative Analysis (JFQA), Forthcoming. Available at SSRN: http://ssrn.com/abstract=1523886

Campbell, J. Y., Lo, A., MacKinlay, A. C. (1997), The Econometrics of Financial Market, Princeton: Princeton University Press.

Chang, E., Llewellen, W. (1984), "Market timing and mutual fund investment performance", Journal of Business, 57(1):57-72.

Chen, H., Jegadeesh, N., Wermers, R. (2000), "The value of active mutual fund management: an examination of the stockholdings and trades of fund managers", Journal of Financial and Quantitative Analysis, 35 (3):343-368.

Chun, R. M. (2000), "Compensation Vouchers and Equity Markets: Evidence from Hungary", Journal of Banking and Finance, 24:1155-78.

Claessens S., Dasgupta S., Glen J. (1995), "Return behaviour in emerging Stock Market", The World Bank Economic Review, 9(1):131-151.

Coggin, T., Fabozzi, F., Rahman, S. (1993), "The investment performance of U.S. equity pension fund managers: An empirical investigation", Journal of Finance, 48(3):10391055.

Cohen, S. I. (2001), "Stock performance of emerging markets", The Developing Economies, 39 (2):168-188.

Cremers, M., Petajist, A. (2009), "How Active Is Your Fund Manager? A New Measure That Predicts Performance“, Review of Financial Studies, 22: 3329-3365.

Daniel, K., Grinblatt, M., Titman, S., Wermers, R. (1997), "Measuring mutual fund performance with characteristic-based benchmarks", Journal of Finance, 52(3):1035-1058.

De Santis, G., Imrohoroglu, S. (1997) "Stock returns and volatility in emerging financial markets", Journal of International Money and Finance, 16 (4): 561-579.

Dickey, D., Fuller, W. (1979), "Distribution of the Estimators for Autoregressive Time Series with a Unit Root", Journal of the American Statistical Association, 74:427-31.

Dickinson, J.P., Muragu, K. (1994), "Market Efficiency in Developing Countries: A case study of the Nairobi Stock Exchange", Journal of Business Finance \& Accounting, 21(1):133-150.

Eling, M., Faust, R. (2010), "The performance of hedge funds and mutual funds in emerging markets", Journal of Banking \& Finance, 34:1993-2009 
Elton, E., Gruber, M., Das, S., Hlavka, M. (1993), "Efficiency with costly information: interpretation of evidence from managed portfolios", Review of Financial Studies, 6(1):1-22.

Engle, R. F., Granger, C.W.J. (1987), "Cointegration and Error-Correction: Representation, Estimation, and Testing", Econometrica, 55:251-76.

Fama, E. (1970), "Efficient capital markets: A review of theory and empirical work", Journal of Finance, 25(2):383-423.

Fama, E. F., French K. R. (1988), "Permanent and temporary components of stock market prices", Journal of Political Economy, 96:246-273.

Ferson, W., Schadt, R. (1996), "Measuring fund strategy and performance in changing economic conditions", Journal of Finance, 51(2):425-461.

Gilmore, C. G., McManus, G. M. (2001) "Random-Walk and Efficiency Tests of Central European Equity Markets", EFMA 2001 Lugano Meetings. Available at SSRN: http://ssrn.com/abstract $=269510$ or doi:10.2139/ssrn.269510

Gottesman, A., Morey, M. R. (2007), "Predicting emerging market mutual fund performance," Journal of Investing, 16:111-122.

Grinblatt, M., Titman, S. (1989), "Mutual fund performance: An analysis of quarterly portfolio holdings", Journal of Business, 62 (3):393-416.

Grinblatt, M., Titman, S. (1993), "Performance measurement without benchmarks: An examination of mutual fund returns", Journal of Business, 66(1):47-68.

Grossman, S., Stiglitz, J. (1980), "On the impossibility of Informationally efficient markets, American Economic Review, 70(3):393-407.

Gruber, M. (1996), "Another puzzle: The growth in actively managed mutual funds", Journal of Finance", 55(3):783-810.

Harvey C. R. (1994), "Conditional Asset allocation in Emerging Markets", Working Paper, No.4623, Cambridge, MA.

Henriksson, R. (1984), "Market timing and investment performance: An empirical investigation", Journal of Business, 57(1):73-96

Huij, J., Post, T. (2008), "On the Performance of Emerging Market Equity Mutual Funds", Available at SSRN: http://ssrn.com/abstract $=1225670$

Jensen, M. (1969), "Risk, the pricing of capital assets, and the evaluation of investment portfolios, Journal of Business, 42(2):167-247.

Johansen, S. (1991), "Estimation and Hypothesis Testing of Cointegration Vectors in Gaussian Vector Autoregression", Econometrica 59, (6).

Kendall, M. G. (1953), "The analysis of Economic Time-series", The Journal of the Royal statistical Society, 116:11-25.

Khorana, A., Servaes, H., Tufano, P. (2005), "Explaining the size of the mutual fund industry around the world“, Journal of Financial Economics, 78: 145-185.

Kon, S. (1983), "The market-timing performance of mutual fund managers", Journal of Business, 56(3): 323-347

Kothari, S.P., Warner, J. B. (2001), "Evaluating mutual fund performance, Journal of Finance, 56(5):1985-2010.

Lee, C., Rahman, S. (1990), "Market timing, selectivity, and mutual fund performance: An empirical investigation", Journal of Business, 63(2):261-278.

Malkiel, B. (1995), "Returns from investing in equity mutual funds 1971 to 1991", Journal of Finance, 50(2):549-572.

Morck, R.,Yeung, B., Yu, W. (2000), "The information content of stock prices: Why do emerging markets have synchronous stock price movements?", Journal of Financial Economics, 58: 215-260. 
Nivet, J.-F. (1997), "Stock Markets in Transition: The Warsaw Experiment." Economics of Transition, 5:171-83

Ojah Kalu, Karemera (1999), "Random walks and Market efficiency Tests of Latin American Emerging Equity Markets: A Revisit", The Financial Review, 34:57-72.

Poterba, J. M., Summers, L.H. (1988), "Mean reversion of stock prices", Journal of Financial Economics, 22: 27-59.

Shukla, R. (2004), "The value of active portfolio management", Journal of Economics and Business, 56:331-346.

Treynor, J., Mazuy, K. (1966), "Can mutual funds outguess the market?", Harvard Business Review, 44:131-136.

Wermers, R. (2000), "Mutual fund performance: An empirical Decomposition into stock-picking talent, style, transaction costs and expenses", The Journal of Finance, 55(4).

\section{ENDNOTES:}

\footnotetext{
${ }^{1}$ Efficient market hypothesis implies that all available information are reflected in security prices preventing participants to gain above-average returns. According to Fama (1970), depending on completeness and speed of information incorporation in securities prices, there are three levels of informational efficiency: (a) the weak form, (b) the semi-strong form, and (c) the strong form.

${ }^{2}$ Two groups of studies dealing with emerging market efficiency can be distinguished: ones that confirmed weak form efficiency despite the problems of thin trading (Dickinson and Muragu, 1994; Ojah and Karemera, 1999; Chun, 2000; Abrosimova et al., 2002) and others that report significant serial correlation in equity returns (Claessens, Dasgupta and Glen, 1995; Harvey, 1994; Nivet, 1997; Gilmore and Mcmanus, 2001).

${ }^{3}$ In period from the announcement and July 2004 (NMS entered EU on May 1st, 2004), stock prices in the eight Central and Eastern European candidates countries increased on average by over 90 percent in dollar terms compared with the world market index returning about 8 percent during the same period (ECB, 2005).

${ }^{4}$ The first purely index fund on Croatian equity market (OTP Index Fund) strated on December 27, 2007.

${ }^{5}$ VECM is restricted VAR model in which restrictions are embedded into model specification and it is used for nonstationary variables that are cointegrated. VEC specification steers long run comovement between endogeneous variables to converge towards cointegration equilibrium, allowing wide range of short run disturbances from the equilibrium.

${ }^{6}$ Aforementioned number of lags is considered as most appropriate taking into account the facts that small number of lags could prevent test from detecting serial correlation at high-order lags. On the other hand, exaggeration in number of lags employed could reduce the power of test as the significant correlation at one lag may be diluted by insignificant correlations at other lags.

7 Distinction between positive (or persistence) over short horizons and negative (or mean reversion) autocorrelations over long horizons can be practically employed in different trading strategies. In this instance, as the investment horizon lengthens, an investor would invest more (less) in stocks if the relative risk aversion is greater (less) than unity, than if the returns were serially independent.

${ }^{8}$ It should be noted that authors have performed more extensive empirical analysis of CROBEX developments. In particular, CROBEX was tested for autocorrelation in daily, weekly and monthly returns in different subperiods. Aforementioned data are available upon request from the authors.
} 


\title{
STRATEGIJE ULAGANJA U VRIJEDNOSNICE: SLUČAJ HRVATSKE
}

\begin{abstract}
SAŽETAK
Ovaj rad analizira investicijske strategije koje koriste odabrani dionički investicijski fondovi u Hrvatskoj. S tim ciljem koristi se Johansenova kointegracijska metoda kako bi se testirala dugoročna zajednička kretanja između 15 odabranih fondova i CROBEX-a u razdoblju između osnutka pojedinog fonda i kraja 2009. godine. Rezultati analize pokazuju da većina hrvatskih dioničkih fondova replicira dugoročna kretanja tržišnog indeksa, što implicira da se radi o tzv. prikrivenim indeksnim fondovima. Uzmu li se u obzir pronađene neefikasnosti na hrvatskom tržištu kapitala i popratna motivacija fond managera da iskoriste iste, dobiveni rezultati su u određenoj mjeri neočekivani.
\end{abstract}

Ključne riječi: investicijske strategije, tržišna efikasnost, dionički fondovi, kointegracija

JEL CLASSIFICATION CODES: G11, G14, G23 